\title{
Organogenesis of Ballan Wrasse Labrus Bergylta (Ascanius 1767) Larvae
}

\author{
Evgenia Dunaevskaya, Anil B. Amin and Oddvar H. Ottesen* \\ University of Nordland, Faculty of Biosciences and Aquaculture, Norway
}

\begin{abstract}
The organogenesis of ballan wrasse, Labrus bergylta, Ascanius, 1767 larvae was studied during the first 49 days after hatching (DAH) with histological and histochemical methods. During the yolk sac stage (0-9 DAH), a syncytial layer had surrounded the yolk sac. At mouth opening, we distinguished a primordial liver and swim bladder, a buccopharyngeal cavity with gill arch cartilages, an exocrine and endocrine pancreas, and a primordial gastrointestinal tract. By the end of this stage, the heart had become functional, the swim bladder had dilated, olfactory organs and otoliths had developed, the pituitary gland and thyroid follicle could be distinguished, and the eye had become pigmented. During preflexion (10-25 DAH), the swim bladder had inflated, and the renal corpuscles and tubules had joined the collecting duct towards the urinary bladder. Mucous cells were observed, which may provide secretions that protect against abrasion and pathogens, and the density of these cells increased in the buccopharyngeal cavity and oesophagus. During flexion (26-33 DAH), secondary lamellae had developed. Increasing functionality of the digestive system coincided with a shift to the appearance of AB-positive mucous cells in the gill openings and the digestive tract. In addition, pharyngeal teeth had developed, which suggested that food preferences might change to include hard-bodied prey. Stage 4 was mainly characterized by increases in the size and complexity of pre existing organs and structures. At $49 \mathrm{DAH}$, metamorphosis was complete. The temporal sequence of development of the various systems may provide baseline information for aqua culturists and fish biologists in future studies on fish health, feed, feed development, and cultivation of ballan wrasse.
\end{abstract}

Keywords: Ballan wrasse; Larvae; Ontogeny; Organs; Histology; Cleaner fish

\section{Introduction}

The ballan wrasse, Labrus bergylta, Ascanius 1767, is a promising species for use as a cleaning fish for salmon farms in the northern hemisphere, due to their cleaning behaviour and their ability to remain active at low temperatures [1]. It is commonly agreed that a potential increase in the demand for ballan wrasse from the industry must be met by future aquaculture production of this species. Methods have been developed for spawning good-quality eggs [2] in addition, intensive larviculture techniques in small, 100-L experimental tanks [2] have identified suitable conditions for rearing larvae, including appropriate values for salinity, temperature, and photoperiod. Nevertheless, hatchery protocols for juvenile production of this species have not been fully developed; in fact, industry development is in its infancy and has been hampered by unpredictable, variable hatchery production of juveniles.

Detailed knowledge of the reproductive biology and early life history of individual species are important for successful cultivation of fish larvae. The larval stage is a critical period during early life development, because at that stage, significant structural and functional changes occur in organs, tissues, and systems. Proper development of several major anatomical features is required for exogenous feeding. In intensive larval rearing conditions, high mortality has been observed during early development, particularly during the live prey feeding period and weaning $[3,4]$. The time scale of ontogeny may be affected by the general life history and by a number of abiotic and biotic factors, including water temperature and food availability [5].

The differentiation of cells, tissues, and organs progresses in steps, from the embryonic phase to full functionality in the metamorphosed juvenile [6]. Previous studies have described the overall morphological and histological changes that take place during larvae ontogeny for a few species in aquaculture [7-9]. However, there are variations among species in the timing of organ formation, development, and functionality.
The developmental stages of ballan wrasse have been defined with reference to endogenous or exogenous feeding, external features based on morphometric data, pigmentation, and characteristics related to locomotion apparatus and mobility [2]. There are no reports available in the literature on the histological aspects of ballan wrasse organogenesis. Furthermore, little is known about the feeding behaviour or food preferences of ballan wrasse larvae in nature. Future success in developing ballan wrasse as a new species for aquaculture will depend on sufficient knowledge of larval organogenesis.

The present study aimed to describe the main histological and histochemical changes in different organs in ballan wrasse that are linked to physiological maturity, chronological age, and larval length at different stages, from hatching to the end of metamorphosis.

\section{Materials and Methods}

Ballan wrasse eggs were collected in July 2009 from a brood stock maintained at the University of Nordland, Mørkvedbukta Research Station, in Bodø, Norway. The eggs were incubated in the dark, and $50 \%$ hatching occurred at 72 day-degrees $\left({ }^{\circ} \mathrm{C}\right.$ days); i.e., 6 days at $12^{\circ} \mathrm{C}$. Initially, newly hatched larvae that originated from one spawning in one tank were transferred to 100 -L, black, polyethylene tanks for feeding. The water temperature was gradually increased from 11 to $14^{\circ} \mathrm{C}$ over 4 days, with an average temperature of $13.9 \pm 0.9^{\circ} \mathrm{C}$ during the entire experiment.

*Corresponding author: Oddvar $\mathrm{H}$. Ottesen, University of Nordland, Faculty of Biosciences and Aquaculture, 8049 Bodo, Norway, Tel: 4775517485; Fax: 47755 17410; E-mail: oddvar.ottesen@hibo.no

Received June 27, 2012; Accepted August 02, 2012; Published August 12, 2012

Citation: Dunaevskaya E, Amin AB, Ottesen $\mathrm{OH}$ (2012) Organogenesis of Ballan Wrasse Labrus Bergylta (Ascanius 1767) Larvae. J Aquacult Res Dev 3:142 doi:10.4172/2155-9546.1000142

Copyright: (c) 2012 Dunaevskaya E, et al. This is an open-access article distributed under the terms of the Creative Commons Attribution License, which permits unrestricted use, distribution, and reproduction in any medium, provided the original author and source are credited. 
At 4, 5 and 6 days after hatching (DAH), larvae were fed once a day with cultured rotifers Brachionus plicatilis (5-7 rotifers $\mathrm{ml}^{-1}$ ) enriched with Red Pepper (Bernaqua NV Hagelberg 3 B-2250 Olen Belgium). From 7 to $20 \mathrm{DAH}$, larvae were fed three times per day. Algae Chlorella sp. (Pacific Trading Co., Ltd. Fukuoka, Japan) was added to the rotifers $\left(2.5 \mathrm{ml} \mathrm{L}^{-1}\right.$ of rotifers) before they were distributed into the first feeding tanks. To establish green water, algae paste (10-15 ml tank $\left.\mathrm{k}^{-1} \mathrm{day}^{-1}\right)$, which consisted of Nannochloropsis spp. (Nanno 3600, Reed Mari culture Inc, USA), was added according to the manufacturers guidelines; it was diluted 1:10 in seawater and gently poured into the tanks every day at 10:00 hrs. At $20 \mathrm{DAH}$, Artemia sp. (about 1 individual $\mathrm{ml}^{-1}$ ) enriched with Red pepper was introduced to the larvae. From 20 DAH to 27 DAH rotifers weregradually replaced by Artemia, thus, co-feeding was performed for 7 days.

The fish larvae were randomly collected from the rearing tanks daily for the first $9 \mathrm{DAH}$, then every $4^{\text {th }}$ day until 49 DAH. Each sample contained 4-6 larvae. Larvae were anesthetized in $70 \mathrm{mg} / \mathrm{l}$ tricaine methanesulfonate (MS-222, Sigma, Argent, USA) and then fixed in a mixture of $10 \%$ paraformaldehyde and 25\% glutaraldehyde (Aldrich Chemical Company, Inc) in cacodylate buffer ( $\mathrm{pH}$ 7.2). Samples were stored at $6^{\circ} \mathrm{C}$ until subsequent morphological and histological studies.

For histological analysis, the fixed larvae were processed with a tissue processor (Shandon Citadel 2000, Thermo Electron Corp., Pittsburg, PA, USA) and embedded in paraffin wax with a paraffin dispenser (Tissue-Tec Wax-Dispenser WD-4, Kunz instruments A/S, Copenhagen, Denmark). Longitudinal sections $(3 \mu \mathrm{m})$ were cut on a Shandon Finesse ME microtome (Shandon Lipshaw, Pittsburgh, PA, USA). Haematoxylin and eosin (HE) stain was used for general histological observations. Periodic acid-Schiff (PAS) and Alcian blue (AB) $\mathrm{pH} 2.5$ staining techniques were used for specific histochemical reactions to visualize carbohydrates and glycoproteins.

Semi-thin sections (250-300 nm) were cut on a Leica EM UC6 ultramicrotome (Leica Mikrosysteme $\mathrm{GmbH}$, Wien, Austria) with Histo Diatome H11692 knife (Diatome, Switzerland). Sections were stained with toluidine blue stain (TB) for $20 \mathrm{~s}$. Sections were examined with an Olympus BX 51 microscope (Olympus, Japan) and photographed with a digital camera (Olympus Camedia C-3040, Olympus, Japan). Further assessment of selected micrographs were performed with the Cell $\wedge \mathrm{B}$ program (Olympus, Japan).

\section{Results}

The ontogeny of ballan wrasse larvae is divided into four different stages, based on developmental characteristics and feeding schedules (Table 1 ) [2].

\section{Endogenous Reserves}

\section{Digestive system}

At hatching, ballan larvae exhibited a homogenous yolk sac matrix (Figures 1A and 1B). In gross examinations, small oil drops were observed in the yolk sac before preparations for histological investigation. Oil drops could not be distinguished in histological sections. The yolk was surrounded by a syncytial layer of flattened epithelial cells that comprised the periblast or vitelline envelope (Figures 1A, 1B and 1F).

During yolk resorption, the yolk sac matrix appeared granular at the periphery of the yolk sac (Figures 2A and 2D). The lecitoexotrophic period of the yolk sac stage started at $7 \mathrm{DAH}$, at the moment of

\begin{tabular}{|l|l|l|l|l|}
\hline Stage & Age (DAH) & ${ }^{\circ} \mathrm{C}$ days & TL, $\mathrm{mm}$ & Food source \\
\hline $\begin{array}{l}\text { 1. Yolk sac larva } \\
\text { a. Lecitotrophic } \\
\text { b. Lecitoexotrophic }\end{array}$ & $0-6$ & $10.5-71.0$ & $3.64-4.46$ & Endogenous \\
\hline 2. Preflexion larva & $10-25$ & $84.8-108$ & $4.40-4.28$ & Endo- and exogenous \\
\hline 3. Flexion larva & $26-33$ & $355.0-456.4$ & $5.25-5.90$ & Exogenous \\
\hline 4. Postflexion larva & $34-49$ & $470.8-685.7$ & $5.90-10.52$ & Exogenous \\
\hline
\end{tabular}

$\mathrm{DAH}$ : days after hatching; ${ }^{\circ} \mathrm{C}$ days: degree-days; $\mathrm{TL}$ : total length.

Table 1: The main developmental stages of Labrus bergylta larvae and the feeding schedule during the first $49 \mathrm{DAH}$ after hatching are shown [2].
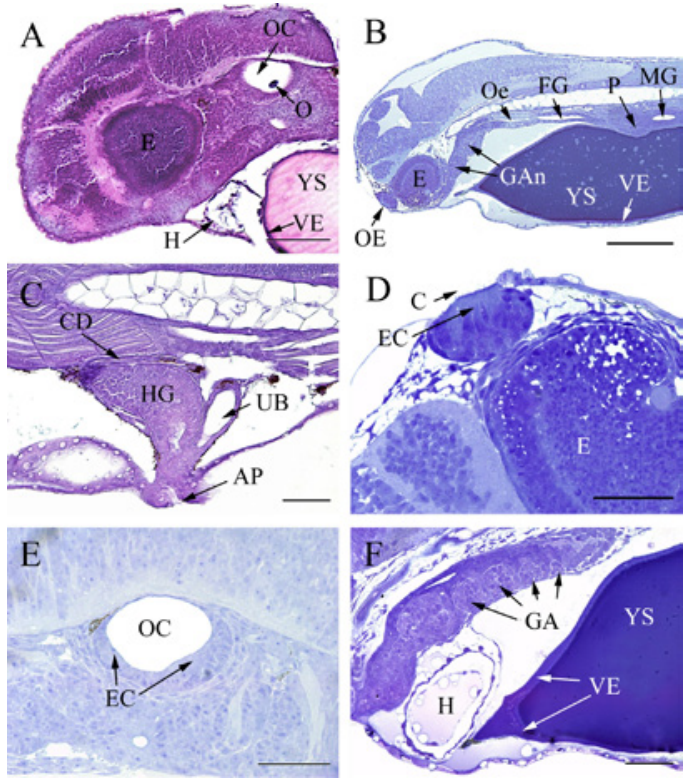

Figure 1: Microsections of ballan wrasse Labrus bergylta larvae during stage 1. (A) Larva at hatching. (B) Larva at hatching. (C) Excretory system at hatching. (D) Olfactory organ at hatching. (E) Inner ear at hatching. (F) Gill arches at 1 DAH. AP-anal pore; C-cilia; CD-collective duct; E-eye; E -epithelial cells; FG-foregut; GA-gill arches; GAn-gill arches anlage; H-heart; HG-hindgut; MG-midgut; O-otolith; Oe-oesophagus; OC-otic capsule; OE-olfactory epithelium; P-pancreas; VE-vitelline envelope; UB-urinary bladder; YS-yolk sac. Bars: $A=100 \mu \mathrm{m} ; B=200 \mu \mathrm{m} ; C-F=50 \mu \mathrm{m}$. Staining: $A=H E ; B, D-F=T B$; $\mathrm{C}=\mathrm{AB}-\mathrm{PAS}$.

first feeding, when the mouth and anus were opened. This period was characterized by the coexistence of endogenous (yolk sac) and exogenous (rotifers) food sources. The yolk sac was completely resorbed by the beginning of the preflexion stage at $10 \mathrm{DAH}$, when the exotrophic period began.

Digestive tract: The digestive tract comprised a straight tube, slightly differentiated into regions, attached dorsally to the yolk sac, and lined by a single layer of cuboidal/columnar epithelial cells (Figure 1B). The widened posterior part of the digestive tract (hindgut) was bent ventrally (Figure $1 \mathrm{C}$ ), and the mouth and anus were closed (Figures $1 \mathrm{~A}, 1 \mathrm{~B}$ and $1 \mathrm{C})$.

At $3 \mathrm{DAH}$, the lumen in the hindgut region became wider, and the anal pore (Figure 2B) and mouth opened (Figure 2E). Also, at 3 $\mathrm{DAH}$, the digestive tract had differentiated into regions, including the buccopharyngeal cavity, oesophagus, foregut, midgut, and hindgut (Figures 2A and 2B).

After the mouth opened, the lumen in the intestine became wider; by $7 \mathrm{DAH}$, a brush border and granules appeared in the intestinal 

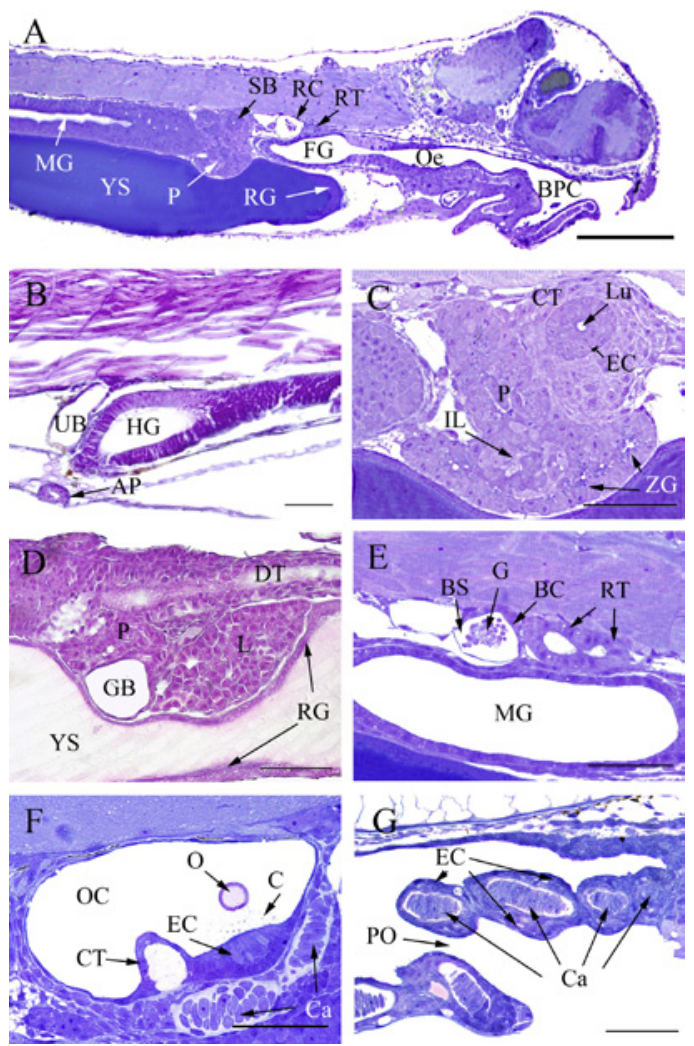

Figure 2: Microsections of ballan wrasse Labrus bergylta larvae during stage 1 (3 DAH). (A) Larva. (B) Opening of anal pore. (C) Pancreas and swimbladder. (D) Accessory glands. (E) Excretory system. (F) Inner ear. (G) Gills. AP-anal pore; BC-Bowman's capsule; BPC-buccopharyngeal cavity; BS-Bowman's space; C-cilia; CT-connective tissue; Ca - cartilage; DT-digestive tract; ECepithelial cells; FG-foregut; G-glomeruli; GAC-gill arches cartilage; GB-gall bladder; HG-hindgut; IL-islet of Langerhans; L-liver; Lu-lumen; MG-midgut; O-otolith; Oe-oesophagus; OC-otic capsule; P-pancreas; PO-pharynx opening; RC-renal corpuscle; RG-resorptive granules; RT-renal tubules; Sstomach; SB-swim bladder; UB-urinary bladder; YS-yolk sac, ZG-zymogen granules; YS-yolk sac. Bars: $A=200 \mu \mathrm{m} ; B-G=50 \mu \mathrm{m}$. Staining: A, C, E, F, $\mathrm{G}=\mathrm{TB} ; \mathrm{B}, \mathrm{D}=\mathrm{HE}$.

epithelium, folds had formed (Figure 3D), and digested rotifers were observed along the entire digestive tract. From the beginning of the co-feeding period at $25 \mathrm{DAH}$, only rotifers were digested in the intestine, and undigested Artemia were observed in the digestive tract. At $29 \mathrm{DAH}$, partly digested Artemia were observed in the midgut, and numerous folds were observed in the midgut and hindgut. At $37 \mathrm{DAH}$, digested Artemia were observed along the entire digestive tract.

Oesophagus and buccopharyngeal cavity: At hatching, the oesophagus was a short, simple tube, similar to an incipient gut, which closed off the digestive tract before the buccopharyngeal cavity had developed (Figure 1B). It was lined by a single layer of simple epithelium.

At $7 \mathrm{DAH}$, some mucous cells appeared (Figure 3C). These increased in number in the oesophagus and buccopharyngeal cavity during subsequent development (Figures $4 \mathrm{~A}$ and $4 \mathrm{~B}$ ). The first taste bud was observed at $17 \mathrm{DAH}$.

At 29 DAH, PAS-positive staining revealed the first mucous cells in the gill opening. At $33 \mathrm{DAH}, \mathrm{AB}$-positive mucous cells were observed. After that, the number of mucous cells increased in the gill opening (Figure $4 \mathrm{~F}$ ), and most were AB-positive.
By $13 \mathrm{DAH}$, the pharyngeal teeth follicles were observed in the connective tissue underlying the buccopharyngeal epithelium in the upper and lower jaws. Teeth were fully developed by 29 DAH (Figure $4 \mathrm{C})$.

Pancreas: At hatching, the incipient pancreas, formed by polygonal shaped cells, was detected between the yolk sac and the developing digestive tract (Figure 1B). At $3 \mathrm{DAH}$, exocrine pancreatic acinar
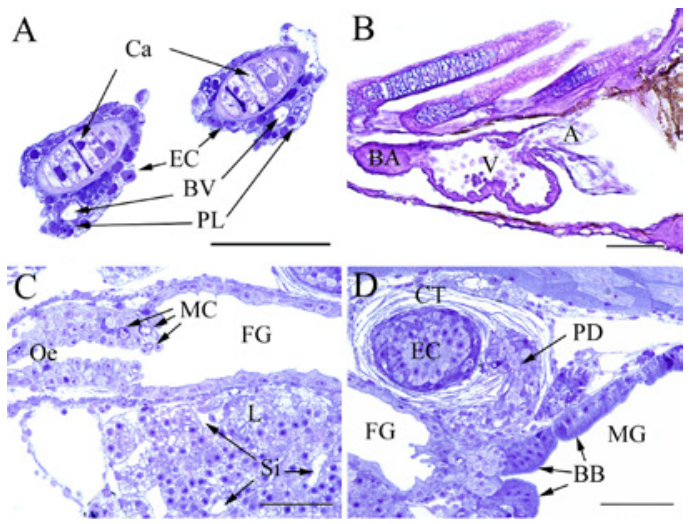

Figure 3: Microsections of ballan wrasse Labrus bergylta larvae during stage 1(7 DAH). (A) Gill arches. (B) Heart. (C) Digestive system. (D) Swim bladder and midgut. A-atrium; BA-bulbus arteriosus; BB-brush border; BV-blood vessel; CT-connective tissue; EC-epithelial cells; FG-foregut; $\mathrm{Ca}$ - cartilage; L-liver; MC-mucous cells; MG-midgut; Oe-oesophagus; PL-primary lamellae; PD-pneumatic duct; Si-sinusoid; V-ventricle. Bars: $A-D=50 \mu \mathrm{m}$. Staining: $A, C, D=T B ; B=A B-P A S$.

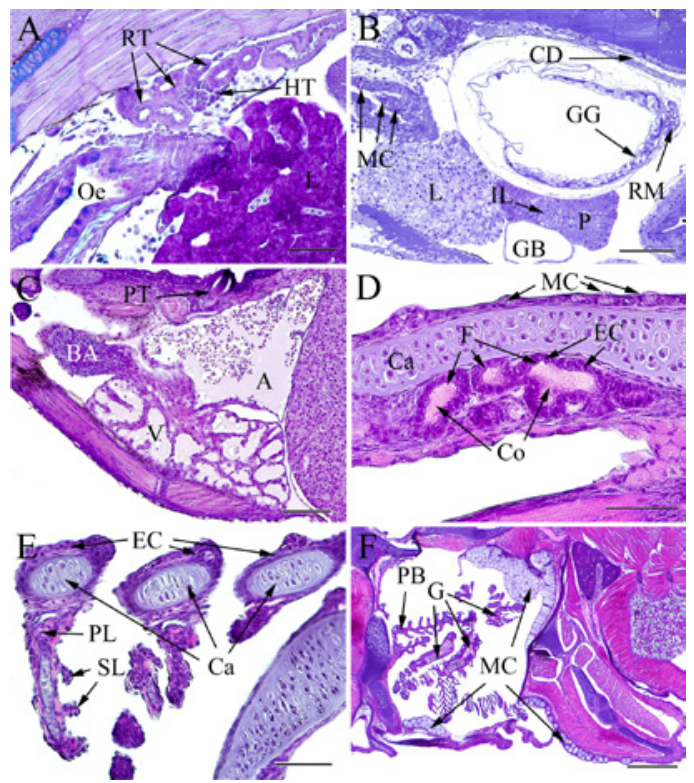

Figure 4: Microsections of ballan wrasse Labrus bergylta larvae during stages 2-4. (A) Kidney17 DAH. (B) Swim bladder at $23 \mathrm{DAH}$. (C) Heart at $29 \mathrm{DAH}$. (D) Thyroid at $29 \mathrm{DAH}$. (E) Gill arches at $29 \mathrm{DAH}$. (F) Gill opening at $49 \mathrm{DAH}$. A-atrium; BA-bulbus arteriosus; Co-colloid; Ca-cartilage; CD-collecting duct; EC-epithelial cells; F-follicles; G-gills; GB-gall bladder; GG-gas gland; HT-haematopoietic tissue; IL-islet of Langerhans; L-liver; MC-mucous cells; Oe-oesophagus; P-pancreas; PB-pseudobranch; PL-primary lamellae; PT-pharyngeal tooth; RM-rete mirabile; RT-renal tubules; SL-secondary lamellae; V-ventricle. Bars: A, D, $E=50 \mu \mathrm{m} ; \mathrm{B}, \mathrm{C}=100 \mu \mathrm{m} ; \mathrm{F}=200 \mu \mathrm{m}$. Staining: $A=A B-P A S ; B=T B ; C-F=H E$. 
pyramidal cells had concentrated between the swim bladder, the yolk sac, and the intestine (Figures 2A and 2C). The first zymogen granules were apparent in acinar cells in the central, luminal part of the glands. Endocrine cells could be distinguished in an islet of Langerhans formation (Figure 2C). After the beginning of first feeding, the size of the pancreas and the number of zymogen granules increased.

Liver: At hatching, the liver was not evident. At $3 \mathrm{DAH}$, the primordial liver was first observed as a small cluster of undifferentiated, rounded cells behind the anterior quarter section of the yolk sac (Figure 2D). By $7 \mathrm{DAH}$, hepatocytes were tightly packed between sinusoids. Their cytoplasm harboured a prominent, central, vesicular nucleus and glycogen-containing granules (Figure 3C). After that, the liver showed positive PAS staining, and it increased in size in subsequent stages.

Gall bladder: The gall bladder was first observed at 3 DAH, lying between the liver, pancreas, and yolk sac (Figure 2D). It was lined by a single layer of cuboidal epithelial cells. During stages 3 and 4, the organ increased in size and became more curved and elongated.

\section{Sensory and nervous system}

Eyes: The newly hatched larvae had immature, unpigmented eyes (Figures 1A and 1B). The lens was spherical and optic nerves were discernible. Eye pigmentation started at $1 \mathrm{DAH}$ and was complete by $7 \mathrm{DAH}$.

Inner ear: Newly hatched larvae had simple, round-shaped, otic capsules that contained discernible otoliths (Figure 1A). Capsules were lined with a simple cuboidal epithelium (Figure 1E). At $3 \mathrm{DAH}$, connective tissue formed that separated the capsule into semicircular canals, and a cartilaginous wall began to develop around the otocyst. In addition, ciliated sensory epithelium was observed (Figure 2F). During larval development, the canals ossified and increased in size.

Olfactory organ: At hatching, a bilateral region of ciliated olfactory epithelium was discernible (Figures 1B and 1D). With larval growth, the olfactory area became larger, the sensory epithelium area increased, and the sensory epithelium had submerged under the skin.

Excretory system: At hatching, a primordial pronephric collecting duct was connected to the urinary bladder. It ran just below the notochord axis and above the gut. The urinary bladder anlage was visible in the vicinity of the anus; it was discerned as a closed-wall sac lined with a simple layer of low columnar and cuboidal epithelial cells (Figure 1C). At $3 \mathrm{DAH}$, the epithelial cells that lined the lumen of the urinary bladder appeared flattened (Figure 2B). Starting at $3 \mathrm{DAH}$, during the yolk sac stage, primary renal tubules appeared and began convolution (Figure 2E); this increased during the exotrophic period, and became pronounced in the cephalic region (Figure $4 \mathrm{~A}$ ). Also at $3 \mathrm{DAH}$, the first renal corpuscle became connected to its proximal convoluted renal tubule (Figure 2A). The corpuscle comprised a Glomerulus, Bowman's space, and a Bowman's capsule (Figure 2E). At 9 DAH, scant numbers of haematopoietic cells were observed between tubules. At $17 \mathrm{DAH}$, a moderate number of haematopoietic cells ware observed between the renal tubules (Figure 4A). In the subsequent days, the proximal renal tubules and haematopoietic tissue proliferated, which led to a notable increase in kidney size.

\section{Other organs}

Gills: At hatching, the gill anlage was discernible in the region of the closed buccopharyngeal cavity (Figure 1B). At 1 DAH, the four primordial gill arches were distinguishable (Figure 1F). At $3 \mathrm{DAH}$, gill structures were observed that comprised cores of chondroblasts covered with undifferentiated epithelium, and the pharynx had opened (Figure 2G)

At $7 \mathrm{DAH}$, four separate gill arches were clearly distinguished. These structures, (undifferentiated epithelial cells surrounding a core of chondroblasts) proliferated towards a cavity formed by the primary lamellae with captured blood vessels (Figure 3A). By 29 DAH, anlages of secondary lamellae were observed in gill filaments (Figure 4E).

At $9 \mathrm{DAH}$, the pseudobranch anlage was first observed as a structure of undifferentiated cells. Subsequently, the pseudobranch continued to develop, and by $25 \mathrm{DAH}$, the appearance and proliferation of filaments and lamellae were evident. During stages 3 and 4 , the organ noticeably increased in length and in the numbers of filaments and lamellae (Figure 4F).

Skin: In newly hatched larvae, the number of cell layers in the epidermis varied between 1 and 2. Epithelial, saccular, and a few mucous cells were observed. In the dermis, scattered melanophores were observed, mostly in the head region and around the yolk sac. A thin layer of pigment cells was observed outside the eyes.

At $1 \mathrm{DAH}$, the number of mucous cells had increased, and they could be distinguished from other cells by AB-PAS staining, which stained the mucous cells purple. The cells were oval or round in shape, and they contained a compact distribution of round or irregular globules. During larval development, the skin became thicker as the epidermal cell layers increased, and the pigmentation intensified.

Heart: At hatching, the heart was observed in the anterior zone, near the yolk sac. The heart tube lumen contained groups of undifferentiated cells and the primordia of the three cardiac compartments (Figure 1A). At $7 \mathrm{DAH}$, the heart had differentiated into 3 chambers: the atrium, with a narrowing towards the ventricle; a ventricle, with thickenedwalls, a large lumen, and blood cells inside; and the thick-walled bulbus arteriosus, which connected to the ventral aorta (Figure 3B). The narrow passage between the atrium and the ventricle constituted the sketch of a atrioventricular valve, which formed later.

At $17 \mathrm{DAH}$, the first myocardial trabeculae were observed in the ventricle, and at $29 \mathrm{DAH}$, the first atrial trabeculae were visible (Figure 4C). At the flexion stage, trabecula proliferation was evident, and defined compartments and the sinus venosus had completely differentiated. These events and the completion of valve formation led to the complete compartmentalization of the heart.

Swim bladder: At $3 \mathrm{DAH}$, the primordial swim bladder had differentiated from the dorsal wall of the digestive tract (Figure 2A). This structure possessed a thick epithelial wall composed of columnar cells, a small irregular lumen, and it was surrounded by connective tissues (Figure 2C). At 7 DAH, the pneumatic duct, which connected the swim bladder to the digestive tract wall, was observed in the posterior region (Figure 3E) at that time, the swim bladder first began to dilate. Concomitant with bladder inflation, from $13 \mathrm{DAH}$, in the ventral zone of the chamber, the cells of the gas gland began to arrange in a single layer, adjacent to an outer layer of rete mirabile (Figure 4B).

Thyroid: At 9 DAH, the thyroid follicle was first observed, located under the lower jaw, along the ventral aorta. The number of thyroid follicles increased progressively in subsequent days. Each follicle was covered by cuboidal epithelial cells and contained pink-stained colloid, the storage form of the thyroid hormone (Figure 4D).

Pituitary: At $5 \mathrm{DAH}$, the pituitary gland was first observed. It was 
located on the ventral surface of the brain, at the mid-line.

\section{Discussion}

The sensory organs of the ballan wrasse developed rapidly with larval growth. At hatching, the main layers of the eye could be distinguished, but the eyes were unpigmented and non-functional, similar to hatching observations previously described for many other marine fish species $[10,11]$. At the time of first feeding $(7 \mathrm{DAH})$, the larvae had developed eyes, olfactory organs, and inner ears; all important for orientation in the environment and predation. The inner ear development was closely related to larvae swimming behaviour. At hatching, the otic capsule was roundshaped, coincident with the inability to swim horizontally; this limited the larvae to up and down movements in the tank. In subsequent days, the larvae swam more actively, and they could swim horizontally for short periods of time. This behaviour was linked to the initial development of semicircular canals. These observations were consistent with those reported for African catfish (Clarias gariepinus) [12].

The developing fish larvae obtains nutrition by endocytosis of the yolk sac through a syncytial layer [13]. The digestive tract in $L$. bergylta larvae developed before the onset of exogenous feeding. At the time of mouth opening ( $3 \mathrm{DAH}$ ), it was possible to distinguish the buccopharyngeal cavity, oesophagus, primordial foregut, and the intestine, divided into midgut and hindgut. These main developmental events were consistent with previous reports in other species, like the gilthead sea bream [14] and common pandora (Pagellus erythrinus) [15]. At $10 \mathrm{DAH}$, the yolk in ballan wrasse had completely resorbed; and the standard length of larvae was $4.3 \mathrm{~mm}$, comparable to data reported by Artuz [16]

At $7 \mathrm{DAH}$, the first PAS-positive mucous cells in the digestive tract were detected in the oesophageal epithelium. This was the same time that the first digested rotifers were observed in the gut. This indicated that the larvae had acquired the ability to ingest and transport feed particles through the gut, which was facilitated by mucous lubrication. The increasing functionality of the digestive tract was confirmed by the appearance, from $7 \mathrm{DAH}$, of the PAS-positive brush border on the intestinal epithelium. This was most likely related to absorption of digested substances, as suggested for tilapia (Oreochromis niloticus) [17].

At $17 \mathrm{DAH}$, taste buds were detected in the oesophagus of $L$. bergylta larvae. These chemosensory organs consist of modified epithelial cells, and play an important role in gustation, foraging, and food recognition [8]; this suggested that ballan wrasse had developed selectivity in feeding.

At the beginning of the co-feeding period (21 DAH), the appearance of undigested Artemia in the hindgut suggested that brine shrimp was an unsuitable food for ballan wrasse at this stage. However, at $29 \mathrm{DAH}$, digested Artemia were observed in the midgut, and at 37 $\mathrm{DAH}$, they were observed along the entire digestive tract. This was linked to the development of intestinal folds and the appearance of $\mathrm{AB}$ positive mucous cells in the gut epithelium and in the gill opening. ABpositive mucous cells contain carboxylated and sulfated mucous that may provide lubrication and protection against abrasion and pathogens [18]. The simultaneous occurrence of AB-positive mucous cells in the gut and gill openings and the appearance of pharyngeal teeth may indicate an adaptive change to facilitate digestion of more complex food, including hard bodied prey. In adult ballan wrasse, the shells of prey are crushed by the pharyngeal teeth [19]. In cichlids (Lethrinops furcifer), food is sucked from the substrate, and digestible food is retained and transferred to the digestive system, while indigestible particles, like sand and mud, are released through the gill openings [20]. It is not known whether the hard parts of crushed shell, or other hard indigestible material, are released through gill openings in ballan wrasse, but this is a possibility. In that case, the secretions of $\mathrm{AB}$-positive mucous cells in the gills may also provide lubrication and protection against abrasion when hard particles are released through gill openings.

Primordial liver and gallbladder could be observed at $3 \mathrm{DAH}$, which is later than observations in other species; e.g., Atlantic cod (Gadus morhua) [7]. At $7 \mathrm{DAH}$, and during subsequent development, the liver showed strong PAS-positive staining. This provided evidence of larvae feeding behaviour because it indicated glycogen storage in the liver.

In ballan larvae, the exocrine pancreas was detected at hatching. Similar findings were reported in Atlantic cod [7], but not, e.g., in flatfish brill (Scophthalmus rhombus) [21] or redbanded seabream (Pagrus auriga) [8]. The endocrine part of the pancreas (the islet of Langerhans) was observed during the early yolk sac stage (3 DAH), as in other teleosts; e.g., common pandora [15].

At first feeding, the circulatory system, with a functional heart, was ready to support the organs involved in the digestive process. Generally, respiration in fish larvae is cutaneous [22]. In L. bergylta larvae, during the yolk sac stage, the epidermis consisted of 1-2 layers of cells that performed respiration and osmoregulation. Pigmented blood cells, containing haemoglobin, were observed at $7 \mathrm{DAH}$. These cells most likely improved the efficiency of cutaneous respiration [23]. As in other species, like the common dentex [9], L. bergylta gill arch anlages were distinguished at hatching, and at $3 \mathrm{DAH}$, cartilage of gill arches were observed in the buccopharyngeal cavity. It is known that gills become functional when secondary lamellae develop [24]. In ballan larvae, this occurred during the preflexion stage. As larvae grow, the integument thickens with increasing cell layers; this reduces the permeability of the skin for cutaneous respiration [6]. In addition, with growth, the ratio of size to surface area changes, and the integument becomes insufficient for adequate respiration. Thus, a more efficient organ for respiration becomes necessary. Accordingly, at $29 \mathrm{DAH}$, secondary gill lamellae had developed in L. bergylta, indicating a transition from cutaneous to branchial respiration, as shown in Atlantic cod [23,25].

The primordial swim bladder appeared in L. bergylta larvae a few days after hatching. This was consistent with observations in other species, like redbanded seabream [8].The swim bladder inflated during the lecitoexotrophic and exotrophic periods, as the functionality of the digestive system increased; thus, an improved ability to manoeuvre and swim was linked to increased feeding activity. At the time of first feeding, the swim bladder was present and ready for inflation. The mode of initially filling the swim bladder is not known in ballan wrasse. However, as in many transient physostomes, it probably has to be conducted by gulping air from the water surface; therefore, oil and organic debris should be removed from culture tank water surfaces.

Similar to Atlantic cod [7], during the first stage of development (0-9 DAH), the excretory system became functional in L. bergylta larvae when the renal corpuscles and tubules joined to the collecting duct towards the urinary bladder.

It has been suggested that thyroid follicles and pancreatic islets appear at approximately the same time, and the pituitary gland differentiates at the time of eye pigmentation [26]. In ballan wrasse larvae, the endocrine pancreas and thyroid follicle were first discerned at the beginning and end of the yolk sac stage, respectively. However, the pituitary gland was distinguished at the same time as eye pigmentation 
during the yolk sac stage. Other species, like the redbanded seabream [8], showed earlier development of thyroid hormone. In those species, thyroid hormone appears to be important for metabolism from the time of first feeding through larval development and metamorphosis.

In conclusion, ballan wrasse exhibited some differences from other species in the timing of several ontogenetic events. By first feeding, ballan larvae were able to orientate the body in a water column and orientate towards prey. At the same time, circulating, pigmented blood cells were observed and the digestive system was ready to receive food. Subsequently, further differentiation was observed in the digestive tract, liver, and pancreas. Also at the time of first feeding, the swim bladder was ready for inflation; thus, it will be important to remove oil and organic debris from the water surface of culture tanks. However at first feeding, respiration was performed by the integument. Over time, the integument thickened, and secondary lamellae developed and respiration through gills was achieved at $29 \mathrm{DAH}$. By $37 \mathrm{DAH}$, the larvae were able to digest Artemia, coincident with a trend in maintaining a deeper position in the water column, and increases in $\mathrm{AB}$-positive mucous cells in both the gill slits and the intestine. The purpose of these concurrent developments is unknown, but it could be related to adaptive changes that facilitate managing more complex food and associated feeding behaviors.

This information on ballan wrasse organogenesis may provide a basis for establishing feeding practices, improving health management, and devising effective cultivation techniques for this new species in aquaculture.

\section{Acknowledgments}

We thank the following individuals for technical assistance: Heidi Ludviksen, Jacek Perkowski, Bjørnar Eggen, and Magnus Røkke Mørkvedbukta Research station, University of Nordland, Bodø, Norway, and Randi Olsen, Electron Microscopy Laboratory, University of Troms $\varnothing$, Norway. We address special thanks to Dr. Nonna Zhuravleva for valuable discussions and contributions. This research was partly funded by EU structural funds and the Northern Periphery Program through the EcoFish project, and the MarLip; program University of Nordland, Bodø, Norway.

\section{References}

1. Sayer MDJ, Treasurer JW, Costello MJ (1996) Wrasse: Biology and use in aquaculture. Fishing News Books. Blackwell Science Ltd. London.

2. Ottesen OH, Dunaevskaya E, Arcy JD (2012) Development of Labrus bergylta (Ascanius 1767) larvae from hatching to metamorphosis. J Aquac Res Development 3: 127

3. Battaglene SC, Cobcroft JM (2007) Advances in the culture of striped trumpeter larvae: A review. Aquaculture 268: 195-208.

4. Daniels HV, Watanabe WO, Noga EJ, Smith SA, Ottesen OH (2010) Disease Diagnosis and Treatment. In: Practical Flatfish Culture and Stock Enhancement. lowa State University Press, USA.

5. Falk-Petersen IB (2005) Comparative organ differentiation during early life stages of marine fish. Fish Shellfish Immunol 19: 397-412.

6. Blaxter JHS (1988) Pattern and variety in development. In: Fish physiology, Vol Fish physiology XI. The physiology of developing fish. Part A. Eggs and larvae. (Eds), Hoar WS, Randall DJ. Academic Press, New York.

7. Morrison CM (1993) Histology of the Atlantic cod, Gadus morhua: an atlas Canadian special publication of fisheries and aquatic sciences. Dept of Fisheries and Oceans, Ottawa.

8. Sánchez-Amaya MI, Ortiz-Delgado JB, García-López Á, Cárdenas S Sarasquete C (2007) Larval ontogeny of redbanded seabream Pagrus auriga Valenciennes, 1843 with special reference to the digestive system. A histological and histochemical approach. Aquaculture 263: 259-279.

9. Santamaría CA, Marín de Mateo M, Traveset R, Sala R, Grau A, et al. (2004) Larval organogenesis in common dentex Dentex dentex L. (Sparidae): histological and histochemical aspects. Aquaculture 237: 207-228.
10. Bejarano-Escobar R, Blasco M, DeGrip WJ, Oyola-Velasco JA, Martín-Partido $G$, et al. (2010) Eye development and retinal differentiation in an altricial fish species, the senegalese sole (Solea senegalensis, Kaup 1858). J Exp Zool B Mol Dev Evol 314B: 580-605.

11. Siebeck UE, Marshall NJ (2007) Potential ultraviolet vision in pre-settlement larvae and settled reef fish--a comparison across 23 families. Vision Res 47 2337-2352.

12. Mukai Y, Tuzan AD, Lim LS, Wahid N, Raehanah MSS, et al. (2008) Development of sensory organs in larvae of African catfish Clarias gariepinus. J Fish Biol 73: 1648-1661.

13. Balon EK (1986) Types of feeding in the ontogeny of fishes and the life-history model. Environ Biol Fish 16: 11-24.

14. Elbal MT, García Hernández MP, Lozano MT, Agulleiro B (2004) Development of the digestive tract of gilthead sea bream (Sparus aurata L.). Light and electron microscopic studies. Aquaculture 234: 215-238.

15. Micale V, Garaffo M, Genovese L, Spedicato MT, Muglia U (2006) The ontogeny of the alimentary tract during larval development in common pandora Pagellus erythrinus L. Aquaculture 251: 354-365.

16. Artuz ML (2005) Embryonic and larval development of the ballan wrasse Labrus bergylta Ascanius 1767. Hidrobiologica 10: 98-101.

17. Osman AHK, Caceci T (1991) Histology of the stomach of Tilapia nilotica (Linnaeus, 1758) from the River Nile. J Fish Biol 38: 211-223.

18. Ottesen $\mathrm{OH}$, Olafsen JA (1997) Ontogenetic development and composition of the mucous cells and the occurrence of saccular cells in the epidermis of Atlantic halibut. J Fish Biol 50: 620-633.

19. Larsson HO (1975) Field observation on some labrid fishes (Pisces Labridae). In: Underwater Archaeological Biology: Proceedings of the fourth World Congress of Underwater Activities.

20. Wootton RJ (1998) Ecology of teleost fishes. Chapman and Hall, New York.

21. Hachero-Cruzado I, Ortiz-Delgado JB, Borrega B, Herrera M, Navas JI, et al. (2009) Larval organogenesis of flatfish brill Scophthalmus rhombus L: Histological and histochemical aspects. Aquaculture 286: 138-149.

22. Fallang A, Ramsay JM, Sevatdal S, Burka JF, Jewess P, et al. (2004) Evidence for occurrence of an organophosphate-resistant type of acetylcholinesterase in strains of sea lice (Lepeophtheirus salmonis Kroyer). Pest Manag Sci 60: $1163-1170$.

23. Herbing IHV, Miyake T, Hall BK, Boutilier RG (1996) Ontogeny of feeding and respiration in larval Atlantic cod Gadus morhua (Teleostei, Gadiformes): I. Morphology. J Morphol 227: 15-35.

24. Hoar WS, Randall DJ (1969) Organ systems. In: Fish physiology, Vol. XI, A Academic Press, New York.

25. Hunt I, Boutilier RG, Miyake T, Hall BK (1996) Effects of temperature on morphological landmarks critical to growth and survival in larval Atlantic cod (Gadus morhua). Marine Biology 124: 593-606.

26. Tanaka M, Tanangonan JB, Tagawa M, de Jesus EG, Nishida H, et al. (1995) Development of the pituitary, thyroid and interrenal glands and applications of endocrinology to the improved rearing of marine fish larvae. Aquaculture 135 111-126. 